\title{
Self-Presentation of Indonesian Hijabers on Instagram
}

\author{
Alila Pramiyanti \\ School of Communication, Telkom University
}

\begin{abstract}
This study explores how Indonesian hijabers redefined the self-presentation of hijab-wearing women through social media, specifically Instagram. These Indonesian hijabers, or young Indonesian hijab-wearing women who are fashion-conscious, have embraced the visual affordances of Instagram to perform their unique digital self-portraits. I used digital ethnography to delve into the performance of twenty-six well-educated, middle-class hijabers, aged 20-34, living in Indonesia's big cities of Jakarta, Bandung, Yogyakarta, and Gresik. These hijabers participated in in-depth interviews, participant-observations, and social media observations. Drawing on Goffman's theory of self-presentation, this study revealed how Instagram had highlighted the hijabers self-expression with four key themes: being faithful, self-love, inspirational OOTD, and bukan riya (not showing off). Therefore, these findings indicate the hijabers' self-presentation as modest and empowered young women who have intertwined fashion and faith.
\end{abstract}

Keywords: faithful, fashionable, hijabers, Instagram, self-presentation

\section{Introduction}

Indonesia, located in South-East Asia and the largest archipelago country in the world, is home to $12.7 \%$ of the world's Muslim population. Approximately 20 million Indonesian Muslim women wear hijab (Directorate General of Small Business Industry, 2015). A headscarf that covers women's hair is the most recognisable, and some would argue the most controversial, symbol of Muslim identity (Amer, 2014; Arjana, Fox, \& Ali, 2017). 


\section{$2^{\text {nd }}$ International Conference on Advanced Research in Social Sciences \& Humanities}

In addition to being one of the largest Muslim-majority nations in the world, Indonesia is a relevant site for investigating the relationship between hijab-wearing women and social media for three reasons. First, the large Muslim population makes Indonesia a significant market to study Islamic consumer industry, with the busana Muslim or Muslim/hijab fashion industry developing/expanding substantially since the 2000s (Lewis, 2007), and being the third largest country for the consumption of hijab fashion, behind Turkey, and the United Arab Emirates (State of the Global Islamic Economy Report, 2015).

Second, the development of the Indonesian hijab fashion industry has shown the creative cultures of Indonesian Muslims and a desire to establish Indonesia as the centre of Muslim fashion in Asia in 2018 and the world by 2020 (Directorate General National Export Development, 2015). The fact that Indonesian Muslim women have a different style of hijab that can be differentiated from the Middle Eastern dark-coloured niqab, the Malayans style of baju kurung (tunic), or European and American Muslims' jeans and long sleeves, suggests that Indonesian Muslim women have created their own taste and style of modest fashion.

Third, Indonesians are significant consumers of social media, with 71.6 million Facebook users, 19.9 million Instagram users and 14.5 million YouTube users (Hidayat, 2016). These data are discussed not just to highlight the popularity of Instagram in Indonesia, but also to underline the increasing tech-savviness of Indonesian young people who form a significant component of contemporary South-East Asian consumerism and are driving the expansion of middle classes in the region (Agustina, 2015; Chen et al., 2014). Such expansion entails not merely the production of well-to-do, tech and media-savvy individuals but also creates new kinds of associational and community lives, which are growing around critical commodities including the hijab.

This study examines how the hijabers (a term for hijab-wearing young women who are fashionconscious) as one active group of young, middle-class Indonesian women are redefining the meaning of wearing the hijab through a visual-based social media platform,

Instagram. The "hijabers" are characterised as young, middle-class, and well-educated Muslim women who demonstrate creativity in wearing hijab by marking it as their fashion statement (Beta, 2014; Faiz, 2017). 


\section{$2^{\text {nd }}$ International Conference on Advanced Research in Social Sciences \& Humanities}

\section{Self-presentation on Social Media}

The internet not only provides a portal for information and interaction but also creates a connection where self-expression and self-representation can be enacted in a way that has not been experienced before. Erving Goffman in The Presentation of Self in Everyday Life (1959), proposed a notion of identity construction through the concept of dramaturgy a theatre metaphor that engaging in both front stage and back stage. For Goffman (1959) front stage "may include insignia of office or rank, racial characteristics, clothing, sex, age, and racial characteristics, size and looks, posture, speech patterns, facial expression, bodily gestures and the like" (p. 34). In the front stage, people are conscious of "being observed" and will perform following particular values, norms, and rules while back stage (personal) presentations occur when people visibly turn out to be themselves. Goffman (1959) stated that identity performance could be affected by two things: the appearance (physical look) and the manner (behaviour).

Goffman's framework is still applicable for understanding self-presentation on social media platforms either on text-based platforms such as Twitter (Marwick \& boyd, 2011; Papacharissi, 2012), blogs (Bullingham \& Vasconcelos, 2013) or on a visual-based platform of Instagram (Smith \& Sanderson, 2015; Geurin-Eagleman \& Burch, 2016). Social media users are able to purposefully present themselves and adjust their presentation based on responses and the interactions with their audiences on social media (Hogan, 2010).

On Facebook, the front stage's analogy can be observed through photo browsing, monitoring status updates, and newsfeed (Sas, Dix, Hart, \& Ronghui, 2009). Referring to Sas et al.'s (2009) explanation, the front stage of Instagram can be examined through the photographs, captions, and hashtags. The front stage has become a space where Instagram users use their technology devices to perform their photographs, captions, and hashtags.

Back stage is the process of managing the self to become presentable in the online public space including the process of choosing, editing, censoring, changing, or deleting the posts (Sas et al., 2009). This back stage gives the ability for social media users to create and alter how they want to present themselves and how they want to be viewed (Sas et al., 2009; Smith \& Sanderson, 2015). As Goffman (1959) noted that "while people usually are what they appear to be, such appearances could still have been managed" (p. 77). At that point, Instagram users could manage their selves in several tactics such as posing in particular styles, using photo editing applications, editing the captions, and so on. 


\section{$2^{\text {nd }}$ International Conference on Advanced Research in Social Sciences \& Humanities}

Goffman's (1959) dramaturgical framework also proposed the arts of impression management as he noted that "when an individual appears before others he will have many motives for trying to control the impression they receive of the situation" (p. 26). Schmidt (2013) further elaborates Goffman's (1959) concept as:

"When interacting, people always engage in 'impression management' and provide others with information or cues about their own identity. These include "cues given' (information that is deliberately or even strategically communicated) as well as 'cues given off' (which are provided unconsciously - e.g., aspects of nonverbal communication).... This impression management is not always conscious and reflected but often habitualised and based on social scripts that include certain routines of behaviour in specific situations" (Schmidt, 2013, p. 366).

In other words, Instagram users could actively and carefully organise their self-images on the online public space to create a desirable impression for their followers, as mentioned by Zevallos (2007) "social actors still need to balance, readjust, and reflexively reconstruct their identities as a consequence of their social interactions with other people" (p. 86). However, it does not mean they intentionally want to manipulate their self-presentation because users cannot control nonverbal aspects (i.e. gesture, posture, facial, clothing) that communicated through their images.

Additionally, the visual context of Instagram will generate a different interpretation of selfpresentation as pointed out by Marwick and Boyd (2011) "front stage and back stage are always relative as they depend on the audience, context, and interpretation" (p. 144). Since then, Goffman's notion on the self-presentation is helpful when discussing the performances of veiled Muslim women on Instagram. Therefore, this study will employ Goffman concept of self-presentation to investigates how fashion-conscious Indonesian veiled Muslim women use the visual affordances of Instagram to express an Islamic-themed corporeal aesthetic and then how their performances could build another understanding of modern Muslim self.

\section{The Representation of Muslim Women on Social Media}

The number of Muslim women engaging with the online world is increasing. Piela

(2013a) further found that online newsgroups could enable Muslim women to "not only engage with Islamic sources but also to participate in a collaborative (albeit very messy and fragmented) project of creating a bank of Islamic solutions to problems that can be too personal 


\section{$2^{\text {nd }}$ International Conference on Advanced Research in Social Sciences \& Humanities}

to share in mixed-gender groups. They are also able to participate on their own terms, without being challenged by men" (p. 136). Piela's (2012, 2013a) studies both shows how online discussions could help Muslim women to engage with the online world actively and develop a digital space to find a better interpretation and understanding of Islam.

Muslim women also engaged with an interactive platform like YouTube to express themselves, ideas, and femininity (Peterson, 2016a). These women blended their veiling fashion with a mainstream fashion aesthetic to emphasise their power on "their own appearances and in the process, to shift the larger sensory regime of what is considered attractive, stylish and enjoyable" (Peterson, 2016b, p. 16). Digital media has, therefore, helped create the Muslim woman's new image of being both Islamic and inspired.

The trend of using Instagram by middle-class young veiled women has been discussed by several scholars such as Waninger (2015), Kavakci and Kraeplin (2016), Peterson (2016b) who explore the hijabistas in America, Europe, and the Middle East. All of these studies investigated how Instagram could shape the online representation of young Muslim women who were social media influencers, fashion designers, entrepreneurs, and well-known bloggers.

Though young Indonesian Muslim women are active users of Instagram, only a handful of scholars have explored the interrelationship between technology and hijab-wearing women in Indonesia. Accordingly, Beta (2014) and Aisyah (2016) argued that Indonesian hijabers had been used the visual affordances of Instagram to accentuate their sense of fashion. Meanwhile, Nisa (2018) who explored the Instagram accounts of UkhtiSally (Sister Sally) and Duniajilbab (World of jilbab) found the increasing of proselytising Islam on Instagram. However, Nisa's study did not examine the Indonesian hijabers.

Moreover, those studies all conclude that Instagram has been used to perform the commodification of hijab fashion by high-profile Instagrammers who are leading influencers, bloggers, entrepreneurs, fashions gurus, and fashion designers. Those studies also present the hijabers and hijabistas Instagrammers as a brand and market-driven Muslim woman who tends to be seen as glamorous, high-profile young women. Their visual presentations, helped by Instagram, have changed the interpretation of hijab from out-of-date fashion into a "modern" artifact but how these visual affordances of the ordinary young Muslim women on Instagram are yet to be established. This study will address this limitation by bringing the case of Indonesian hijabers and investigating how these hijabers present their selves on Instagram. 


\section{$2^{\text {nd }}$ International Conference on Advanced Research in Social Sciences \& Humanities}

\section{Methodology}

Building on the research work of Hine (2000, 2015), Ardévol and Gómez-Cruz (2013), and (Pink et al., 2016) this study applied a digital ethnography approach to investigate the unique everyday experiences of Indonesian hijabers in using the visual-based platform of Instagram. This research employed digital ethnography (overlapping) practices including catching up, sharing, exploring, interacting, and archiving (Postill \& Pink, 2012)y on Instagram.

Purposive sampling was the sampling approach used in this research. Purposive sampling provides a strategy to generate potential participants that could give useful data for the research (Patton, 1990; Creswell, 2007). This sampling strategy allowed participants to be chosen according to their suitability as the hijabers who are active in their hijab community program and who are social media users. Depth-in interview and social media observation were used as methods of data collection. The process of data collection was followed by evaluating and interpreting data following Braun \& Clarke's (2012) thematic analysis phases: "1) Familiarising yourself with the data, 2) Generating initial codes phase, 3) Searching for themes phase, 4) Reviewing potential themes phase, 5) Defining and naming key themes phase, and 6) Producing the report" (p. 60-66).

The participants were twenty-six hijabers aged 20-34 years, middle-class, urban women and well educated. These characteristics were chosen following the hijabers' characteristics mentioned by Beta (2014) and Faiz (2017). One participant was a PhD student, one had a master's degree, two women were working on their master degree, and the rest had a bachelor degree and were still university students. Eight participants were entrepreneurs, and most of them are employed in the private sector. They each accessed the internet daily and used their mobile phone to access social media, primarily 'Path' (for family and close friends) and Instagram (for public).

The participants came from Indonesia's large cities; Jakarta (the social, economic, and political centre of Indonesia and the $9^{\text {th }}$ most-Instagrammed city in 2017), Bandung (the centre of Indonesia's fashion industry and awarded a UNESCO creative city), Yogyakarta (the basis of Muhammadyah -- the second most significant Islamic Organisation in Indonesia, and where previous hijab research has been conducted ) and Gresik (in East Java as basis of NU -- the 


\section{$2^{\text {nd }}$ International Conference on Advanced Research in Social Sciences \& Humanities}

most significant Islamic Organisation). All cities influence the culture, fashion, and politics of other Indonesian cities.

\section{Narratives and visualities of the hijabers' self-presentation}

As the phrase "picture can tell a thousand words", participants believe their postings communicate many meanings; therefore, they can express their feelings and thoughts without necessarily to write wordy captions. According to the participants, Instagram has communicated specific images of Muslim women and generated new visual presentations of a hijab-wearing woman.

This study expands four key themes in the hijabers' self-presentation, including 1) Faithfulness, 2) self-love, 3) inspirational OOTD (outfit of the day), and 4) bukan riya (not showing off). These themes were categorised in this order due to the sequence of messages that were explicit to implicitly expressed by the hijabers.

\section{Being Faithful}

Most of the hijabers in this study often posted the Quran verses or hadiths (record of the prophet Muhammad's daily practices) in order to spread Islamic knowledge and express their faithfulness to Allah. They posted Quran verses or hadiths for being faithful. It seems they applied the Islamic principle stated by Prophet Muhammad (peace be upon him), "Convey from me even if it is one verse" (HR Bukhori). In other words, Muslims' responsibility in life, besides the obligation to worship Allah and to honour humanity, is to preach, advocate and disseminate the Islamic values, which in Indonesian is known as dakwah or syiar Islam.

Unlike jihadists or another hardline Muslims who tend to spread dakwah on social media using provocative words in the form of anger or hate speech, these hijabers opted to combine simple quotes, famous slogans with images, or insert beautiful self-portraits as their substance of dakwah on Instagram. Therefore, their gentle dakwah and syiar approaches could elevate the concept of Islam as a peaceful religion. As a participant, Tami, described, her aims in using Instagram for hijrah (continual self-improvement to become more faithful) and to ask other Muslimah to hijrah, then she also likes to post Islamic content. Furthermore, in the interview session, she explained, "even though I did not say frontally 'let us change to become a better person' but I encouraged them to change through my updates or my discussions about Islamic 


\section{$2^{\text {nd }}$ International Conference on Advanced Research in Social Sciences \& Humanities}

studies on social media, this is what I called as dakwah". In Figure 1, she posted a simple quote about the presence of God; "And Allah will be there for those who want to approach Him." Ifa also admitted that she preferred to learn Islamic knowledge without being indoctrinated, and she tried to convey Islamic knowledge without being patronising. She displayed an example of using a meaningful yet straightforward message by posting a CCTV camera pointed at the Arabic word for Allah and the words 'is watching you' (see Figure 2). She also wrote, "Muraqabah is applying the consciousness of Allah always sees and watches ourselves in every condition. Allah always knows what we feel, say, and do". The caption means Allah has a magnificent system to watch every movement in the world more than an actual CCTV camera can observe. Every aspect of the world, without exception, will be known as Allah.

Meanwhile, Sarah realised the importance of syiar in Islam. She said, "I want to keep learning and doing syiar, and I want my postings to give benefits to others". In Figure 3 below, she posted a reminder, "Whoever prays Fajr is under the protection of Allah." Fajr is the obligatory morning prayer before dawn and is a form of obedience and faithfulness to Allah.

In that post, she also reversed the greeting 'Good Morning' into "Morning good, if Allah wills." It means every morning will be good if Muslims pray.

Similar to Sarah, Adinna also considered her postings should benefit others. In the interview session, she explained, "Before posting, I should think what kind of dakwah that I have already conveyed and ask myself: will my posting give benefits to others?". She tried to benefit others by posting "Keep Calm and Carry On" dictum - in this case, amended to refer to Read Al Kahfi and a hadith from An-Nassa' I and Baihaqi; Whoever reads Surah Al-Kahfi on Friday, will have a light that will shine from him from one Friday to the next" (see Figure 4). She adopted the famous slogan originally from the UK, to convey a self-reminder in order to advance faith. 


\section{$2^{\text {nd }}$ International Conference on Advanced Research in Social Sciences \& Humanities}

\section{6 - 8 December ,2019}

Munich, Germany

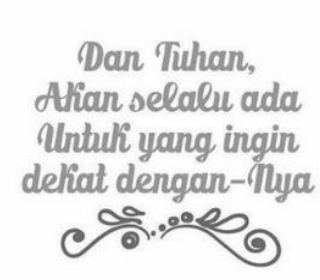

Figure 1 - Allah will be there

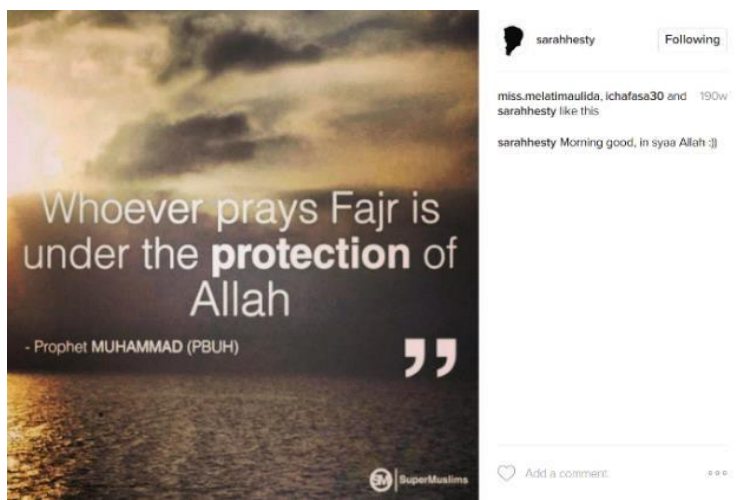

Figure 3 - The protection of Allah

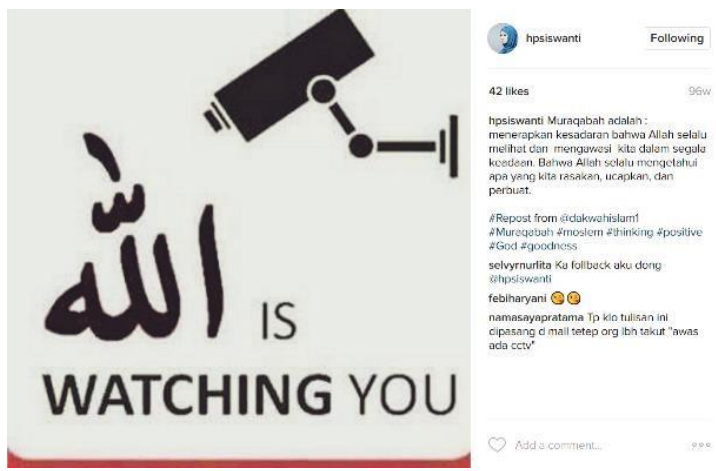

Figure 2 - Allah is watching you

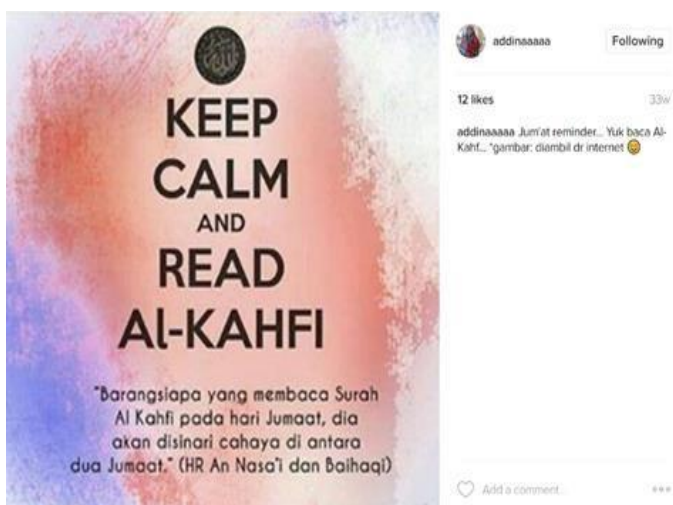

Figure 4 - Keep calm and read Al-Kahfi

Interestingly, these hijabers developed their faithfulness by posting the Quran verses and hadiths, which incorporates their self-portraits in various spaces such as panorama, graveyard, and outdoor sports site. They seem to generate their own version of syiar (preaching Islam) with more exciting and creative modes by engaging with the culture of taking and sharing digital self-portraits. For instance, as the daughter of a famous Indonesian kyai (Islamic leader), Ghaida used Instagram as a channel for dakwah. She firmly stated: "Muslim women should be preaching of Islam, no matter how we are doing it, even though if we still in the process of improving ourselves, we still should convey what we could convey".

In one of Ghaida's posts, she stands under a bamboo tree, wears fashionable pastelcoloured outfits and smiles, all echoing a tranquil milieu (see Figure 5). She cited the Quran verse: “

He who emigrates in the way of Allah will find in the earth enough room for refuge and plentiful resources. Moreover, he who goes forth from his house as a migrant in the way of Allah and His Messenger, and whom death overtakes, his reward becomes incumbent on Allah. Surely Allah is All-Forgiving, All-Compassionate (QS Annissa:100). Happy Friday, everyone! 


\section{$2^{\text {nd }}$ International Conference on Advanced Research in Social Sciences \& Humanities}

She tried to convince herself and her followers that hijrah (continual self-improvement to become more faithful) will lead the way to Allah's blessings. She got 910 likes on that post, which indicates she can reach hundreds of people. Indeed, she recreates her posting, but her narrative emphasises her faithful self.

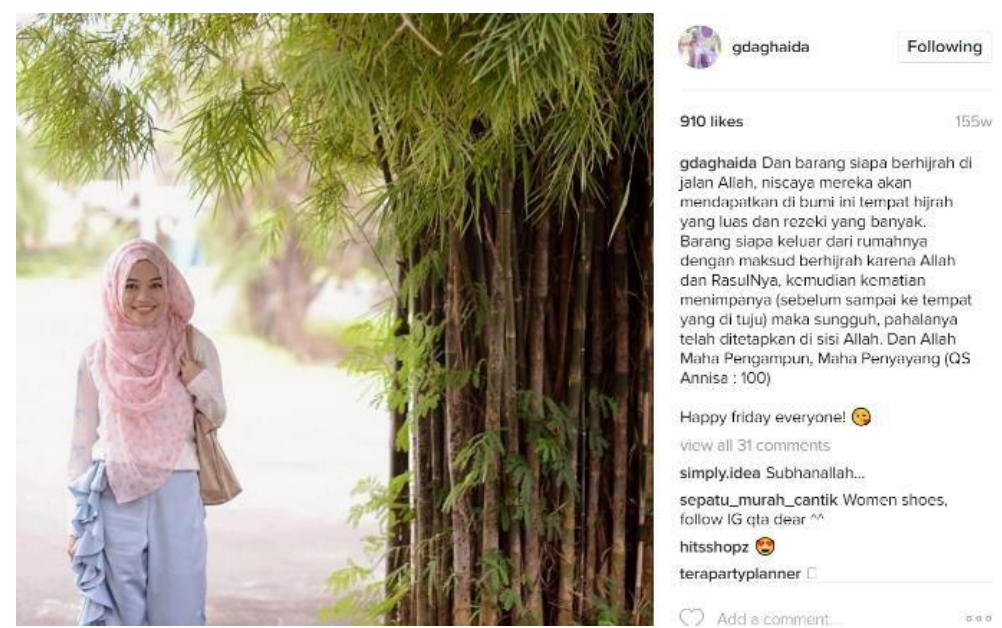

Figure 5 - Migration for the cause of Allah

\section{Self-love}

The majority of hijabers postings signify how they appreciate themselves. It means they have the power to love and believe in themselves. They also help spread messages regarding how women have to value themselves, to know what they want and to recognise their identity. Through their Instagram postings, these hijabers indicated the importance of recognising themselves in order to achieve self-belief as the basis of being empowered. By taking on their power, these hijabers could become role models who encourage their followers to build selfesteem and so create a ripple effect when these positive vibes of self-belief are transmitted from one woman to another. Thus, their empowered selves could amplify their presentation as young Muslim women who embrace the digital public sphere of Instagram for essential purposes.

For instance, Wanda described her full makeup portrait as a masquerade and concealment to highlight her view on the importance of self-worth rather than outer beauty by writing "Fall in love with yourself first. Love yourself enough so when someone treats you wrong, you notice" (see Figure 6). Wanda used Instagram as a platform to express not to impress; then her post 


\section{$2^{\text {nd }}$ International Conference on Advanced Research in Social Sciences \& Humanities}

\section{6 - 8 December ,2019}

Munich, Germany

indicates her consideration to motivate her followers to love themselves in order to respect themselves and to gain respect from others.

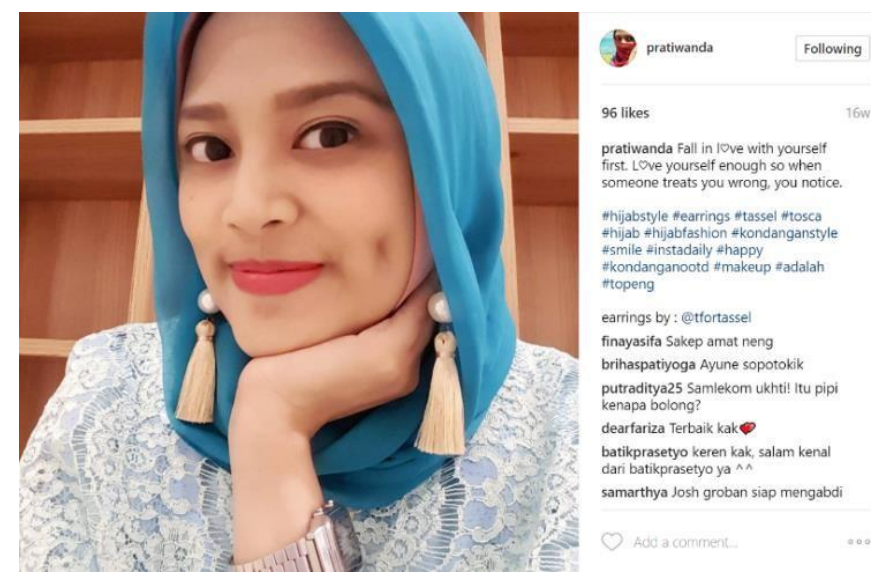

Figure 6 - Fall in love with yourself

Sarah also explained self-love and being comfortable with ourselves is crucial to achieving selfconfidence. As she stated in the interview, "Feeling comfortable about ourselves will raise our self-confident." In her posting, she wrote, "Love yourself, accept yourself. Forgive yourself and be good to yourself." She confidently stands up in front of a sizeable majestic door, probably a mosque door. Her full-body portrait shows her red medium size hijab, a black and white striped blouse, and an A-line skirt (see Figure 7). Her post indicates the power to appreciate herself in order to love herself.
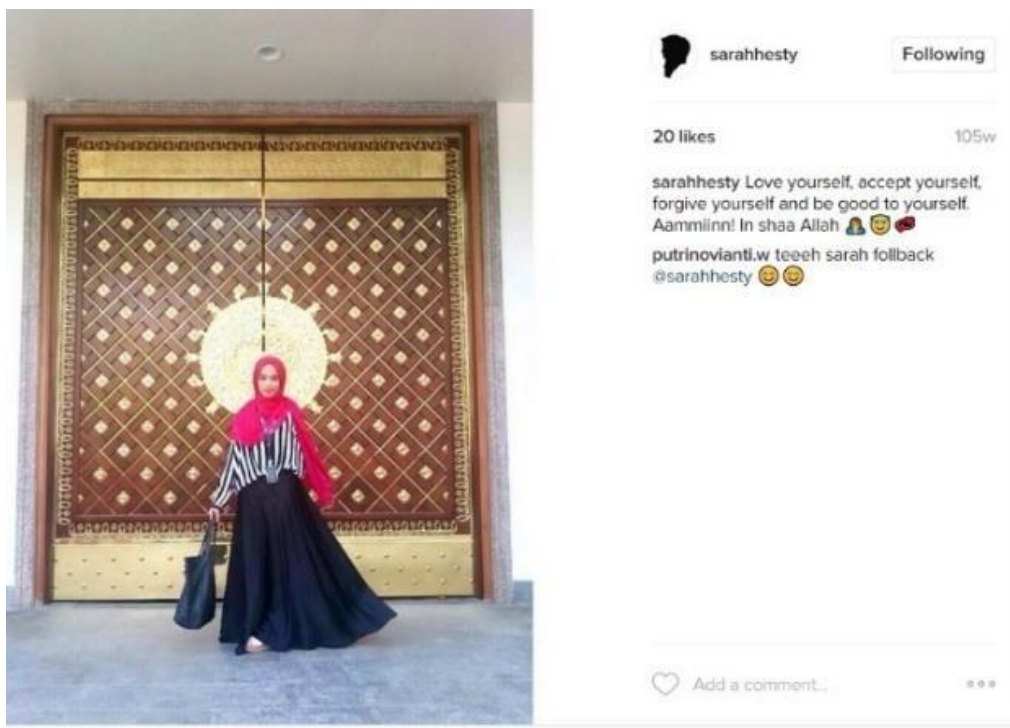

Figure 7 - Love yourself 


\section{$2^{\text {nd }}$ International Conference on Advanced Research in Social Sciences \& Humanities}

Similarly, as a public figure who is involved in several organisations as well as the chairwoman of Hijabers Community, Syifa likes to push herself to the limit because she believes she could achieve whatever she wants as long as she strives for it. She posted a mirror flip selfies' technique with two different portraits. The left portrait showed her close smile, and the right portrait showed her full smile. She stands in front of an art painting, wearing a medium-sized white hijab and a blue blouse and applies a natural makeup colour to her face. She posted a self-belief word by quoting the lyric of Mary J Blige's song, Just Fine (see Figure

8), "Feels so good when you are doing all the things that you want to do. Get the best out of life, treat yourself to something new. Keep your head up high in yourself; believe in you, belief in me." This lyric expressed her aspiration to do what she loves and to love what she does and reflects her willingness to persuade her Instagram followers to advance their self-esteem.

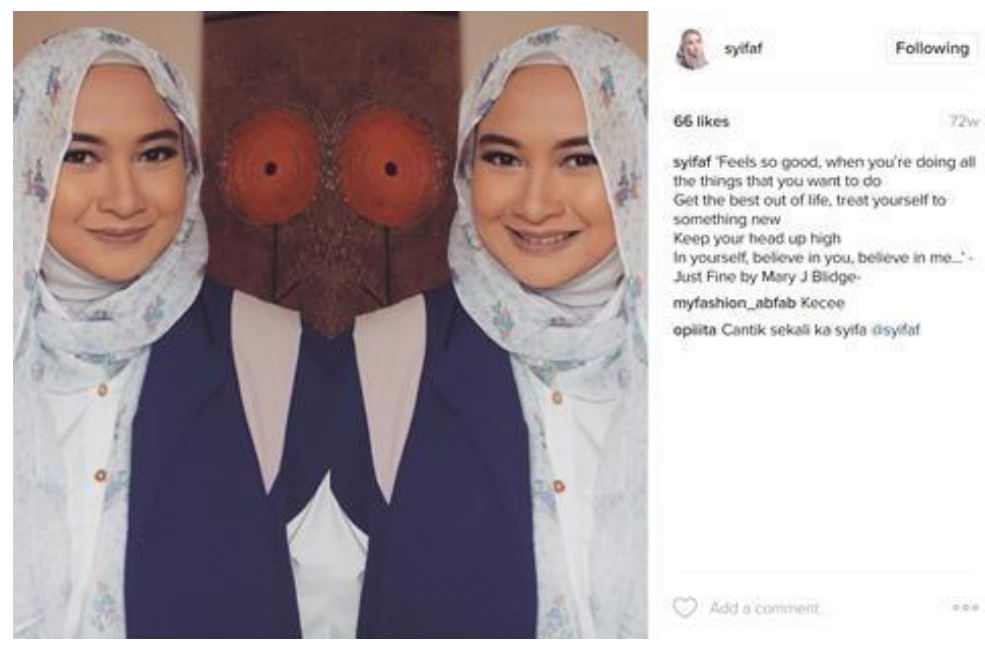

Figure 8 - Believe in yourself

\section{Inspirational OOTD}

Inspirational OOTD is another discourse that can be explored from the hijabers' digital selfportraits. Almost all of the hijabers post \#OOTD; however, this study found interesting points regarding their performances of OOTD. For instance, shown by Irine in Figure 9. Irine wrote an unknown quote "Treat everyone with politeness, even with those who are rude to you, not because they are nice but because you are - unknown". 


\section{$2^{\text {nd }}$ International Conference on Advanced Research in Social Sciences \& Humanities}

Similarly, Ghina prefers to post OOTD than selfies. In the interview session, she said “...If I uploaded selfies, what is the benefit of others? However, if I posted OOTD, they can take the fashion's ideas from my posting".

In figure 10, Ghina wore a green skirt, navy-blue cardigan, and sunglasses while she was posing in a dam's pathway. She captioned an encouraging message "Never be afraid because you are not really alone". In the same way, using a bridge as background, Aez also straight to the point provoked "Life without a dream is sucked!" (see Figure 11). The hijabers added the value of self-esteem within their \#OOTD. Thereby their postings do not look like a fashion catalogue which simply describes what they wear and what brand/price of their outfit is. By writing the narratives within their OOTD, the hijabers tried to not only to share fashion statements but also to stand out their visibility into the digital public sphere. Their OOTD postings have communicated themselves as inspirational young women.

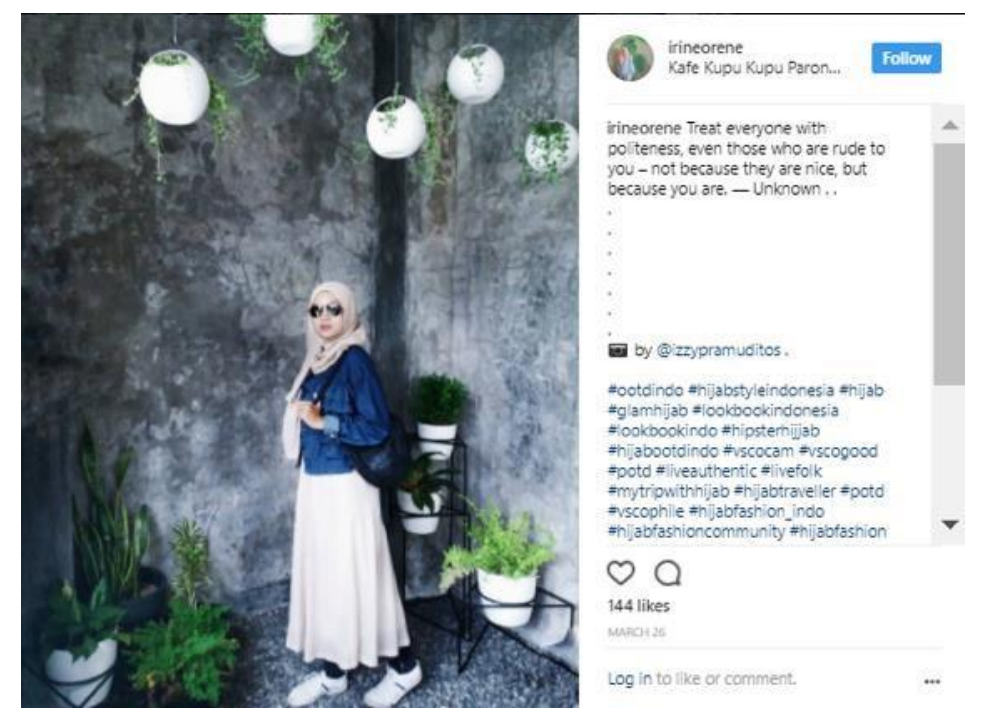

Figure 9. Be polite 

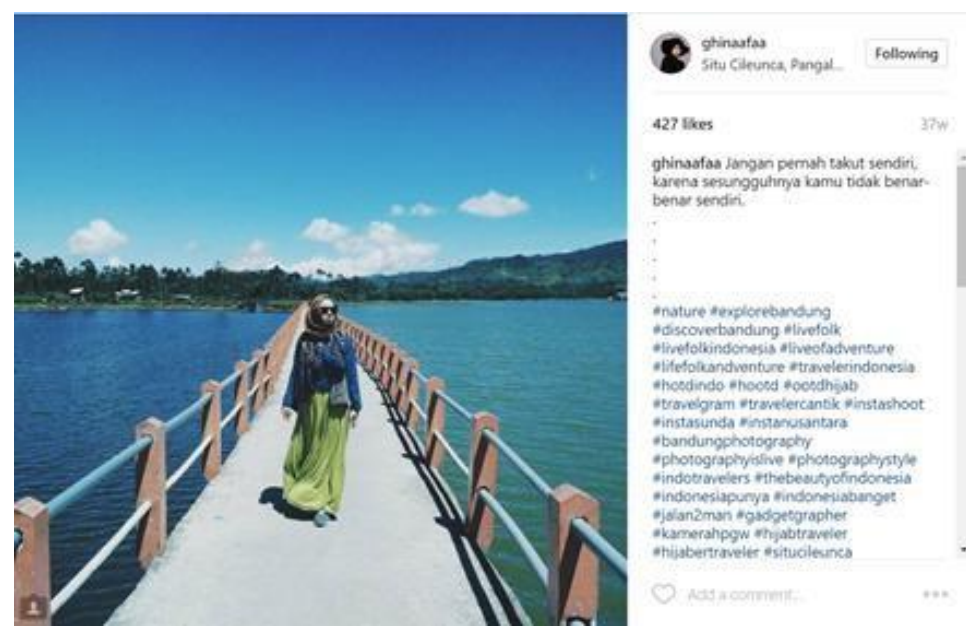

Figure 10. Do not be afraid
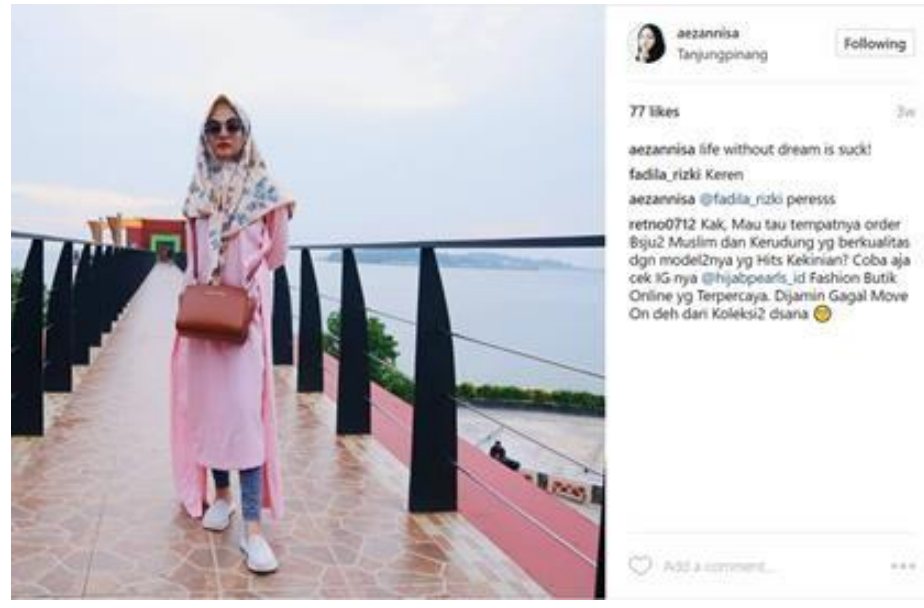

Figure 11. Dream big

\section{Bukan riya (not showing off)}

The discourse of not being arrogant and showing off (bukan riya) also emerged from the hijabers' digital self-portraits. Riya in Arabic, literally means 'shows off'. Someone is categorised as riya when he/she demonstrates worship to expect others' tribute, or to be seen as devoted Muslims, not in order to please Allah. This discourse is meaningful because in the eastern culture, the act of showing off, even in the context of expressing or giving an argument, could be interpreted as superiority which is categorised as rude and unacceptable behaviour.

The hijabers tried to avoid riya, as one participant said, "I have been thinking...social media should be giving benefits, not disturbing other. I want to give benefit; I do not want to show offlarrogant (riya). I updated for good reasons; I do not expect a compliment, I just want to be useful". 


\section{$2^{\text {nd }}$ International Conference on Advanced Research in Social Sciences \& Humanities}

\section{6 - 8 December ,2019}

Munich, Germany

According to Ghaida, social media has created a particular image of Muslimah (an Arabic term for Muslim women), and social media influencers have generated new visual presentations of a hijab-wearing woman. Although she owns her hijab fashion brand and an endorser for sponsors, she wants to give more value to followers other than just talking about 'fashion' in her posts. In Figure 12, Ghaida looks naturally beautiful and composed, while her fingers display the symbol of peace. The discourse of bukan riya is also found in her caption:

Believing Allah is a countless blessing. If every time we feel Allah is watching us, then we will ignore what people think about us, and we will be afraid to do blatant or hidden sins. If every time we believe Allah is always listening, then we do not need to manipulate the words to fascinate others, and we will only have the straight intention and say nothing but the truth. If we conceive our conscience knew by Allah, then we will be terrified, and shame to be arrogant, show off, envy, prejudice.
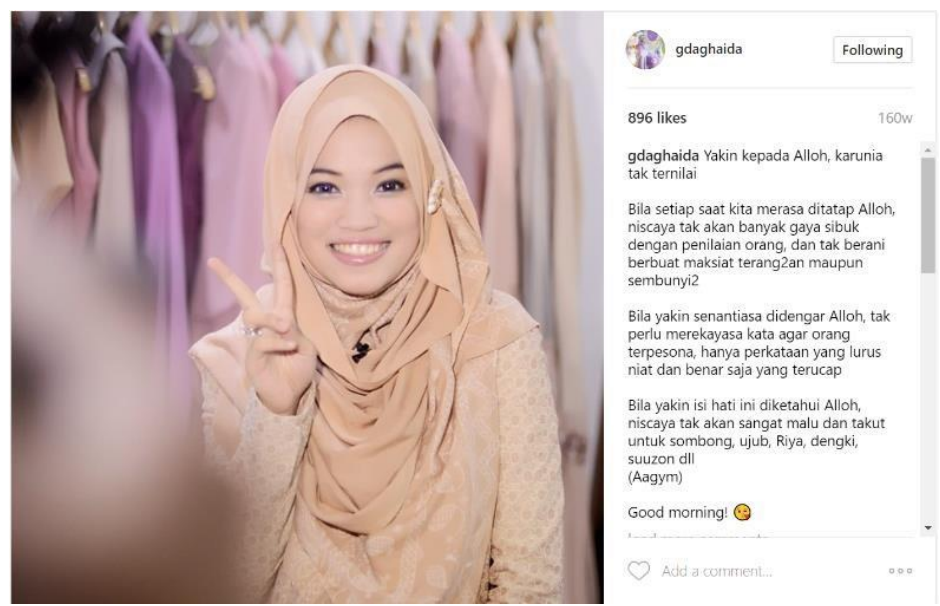

Figure 12 - Fear of appearing arrogant

The concern to avoid being a 'show-off' not only applies in worship-related activities but also is implemented in daily life in general. For example, Elita rarely used Instagram for personal purposes. Even though she recognises the positive aspects of social media, which is very useful for gathering information, sometimes the information is overstated. She, therefore, decided to no longer focus on updating her personal life on social media. She firmly said:

Personally, I instead use social media for some useful manner and not for giving the perception of showing off or exposing as if I am the greatest, the best, the most successful. No, I definitely do not want to display myself like that.

My participants also avoided showing-off, which usually appears when someone showcases their new things or styles. As Ayu stated, "I do not want to look like elite socialites who are 


\section{$2^{\text {nd }}$ International Conference on Advanced Research in Social Sciences \& Humanities}

wearing hijab but showing off their new watches, bags". In a similar tone, Tami also understood that her postings should provide benefit for others rather than make her become arrogant. She said:

Social media should not disturb others. I do not want to show off/arrogant like some women who are wearing hijab just as a fashion item and tend to use social media to show off their styles by saying 'Hey look at me, I am wearing the hijab, and I am stylish'.

The worries of becoming riya or arrogant also relate to the expectation of getting 'like' or 'love' responses from followers. For instance, Sarah said, "I do not want to become showoff...I realised if we are posting something, there is a possibility to make us arrogant". It shows how Sarah prefers her postings not to be liked or loved, rather than she falls to the deeds of riya. By writing bukan riya, these hijabers announce to their followers that there is no intention to show off or be arrogant. Through their postings, they suggest 'let us be devoted Muslim women' by consciously not becoming riya.

\section{Instagram Highlighted Self-expression}

It is long established that the internet expands opportunities for what Goffman (1959) refers to as front stage self-making, and what Sundén (2003) refers to as "typing oneself into being" (p.13). This section explores how my participants' strategy of front and back stage selfmaking on Instagram.

My analysis of my participants' Instagram posts reveals four qualities of their front-stage selfmaking on Instagram: being faithful, self-love, inspirational OOTD, and bukan riya. The front stage self-making indicates their visual presentation through their well-composed photographs, captions, beautiful poses and interesting background.

Even though the hijabers present as stylish, beautiful, photogenic young women, they perform their narratives of modesty. "Modesty is linked to one's level of faith; it is often associated with the level of piety" (Ahmad, 2017:p.274). These narratives disclose their selfconcepts and conceal their consciousness to act for themselves and to be who they are but still follow and promote the Islamic way of life.

Meanwhile, the back stage is the stage of curation where my participants could choose which photographs should be uploaded and with which captions. They need to create positive impressions because they realise they have to present who they really are without generating negative images. Following Thumim's (2012) argument, they stage their selves as "the generic 


\section{$2^{\text {nd }}$ International Conference on Advanced Research in Social Sciences \& Humanities}

expectations of the self-representations" (p. 154). They curate their photographs and captions to confirm what is expected by society from a hijab-wearing woman. For example, they definitely could not post their 'wake-up' faces, because they do not wear their hijab while sleeping. Nor they could post 'bathroom' mirror selfies like Kim Kardashian because they cannot display their aurat (body parts that should be covered). Therefore, back stage is a stage for the hijabers to build impression management which is not always intended to manipulate self-presentation because users cannot control nonverbal aspects (i.e. gesture, posture, facial, clothing).

My proposition about the creation of impression here resonates with Banet-Weiser's (2012) noted that "self-branding seems not only logical but perhaps necessary" (p. 56). She offers an understanding of how brands surround our lives, as a self, we consciously or unconsciously have set up a personal branding that is influenced by our culture, particular life values, and religion. Moreover, her suggestion similar to Goffman's (1959) dramaturgical framework that both front and back stage can be managed but does not have to imply insincerity. While it is not easy to know someone's genuine intention when they engage with social media, the meaning of self-performances on the 'stage' of social media still can be interpreted based on the consistency of how she or he presents and represents themselves.

\section{Conclusion}

The hijabers' self-presentation is worthwhile to explore because they posted different personae from the Western females in term of their narratives and visualities. Their narratives communicate the narratives of faithfulness, perform themselves as modest selves, and represent their fashionable selves. Nevertheless, the narratives within their stylish postings are complemented with positive messages rather than just posting self-portraits with caption \#OOTD. Their captions resonate with their statement in the interview process that said they want to add value to OOTD more than merely being hijabista (hijab and fashionista) and try to avoid for being narcist and riya.

The hijabers front, back stage self-making exhibit styled images which could be seen as an engagement with impression management and consumer cultures. On the other hand, their selfmaking also display faithfulness and modesty. Therefore, the hijabers' postings not only challenge the stereotype of Muslim women as backward and oppressed but also fight 


\section{$2^{\text {nd }}$ International Conference on Advanced Research in Social Sciences \& Humanities}

stigmatisation. Through their postings, the hijabers remain their essence as modest yet confident and fashionable young women who are participating in the modern and digitally world of Instagram.

\section{Reference}

Agustina, H. N. (2015). Hijabers : Fashion Trend for Moslem Women in Indonesia. In Proceeding of International Conference on Trends in Social Sciences and Humanities (TSSH-2015).

Ahmad, N. (2017). How Modest is Modest Fashion? Exploring Notions of Modesty Within the Context of Muslim Women's Hypervisibility on Instagram. In KACP Collaborative Research Report: Gender Justice and Democracy in Asia (pp. 262-296). Asian Association of Women's Studies. Retrieved from http://www.aaws07.org

Amer, S. (2014). What is veiling? Edinburgh University Press. Retrieved from http://www.scopus.com/inward/record.url?eid=2-s2.084944875935\&partnerID=tZOtx3y1

Ardévol, E., \& Gómez-Cruz, E. (2013). Digital Ethnography and Media Practices. The International Encyclopedia of Media Studies, VII, 498-518. https://doi.org/10.1002/9781444361506.wbiems193

Arjana, S. R., Fox, K., \& Ali, W. (2017). Veiled superheroes : Islam, feminism, and popular culture. Lexington Books.

Beta, A. R. (2014). Hijabers: How young urban Muslim women redefine themselves in Indonesia. International Communication Gazette, 74(4-5), 377-389.

https://doi.org/10.1177/1748048514524103

Braun, V., \& Clarke, V. (2012). Thematic Analysis. In H. Cooper (Ed.), APA handbook of research methods in psychology (Vol. 2, pp. 57-71). American Psychological Association. https://doi.org/10.1037/13620-004 Bullingham, L., \& Vasconcelos, A. C. (2013). 'The presentation of self in the online world':

Goffman and the study of online identities. Journal of Information Science, 39(1), 101112. https://doi.org/10.1177/0165551512470051

Chen, L., Akat, H. D., Xin, C., \& Song, S. W. (2014). Rethinking Hijab : Multiple Themes in Muslim Women's Perception of the Hijab Fashion. International Conference on Communication, Media, Technolog and Design, (April), 208-214.

Creswell, J. W. (2007). Qualitative inquiry and research design: Choosing among five approaches (2nd ed.). Sage Publications.

Directorate General National Export Development. (2015). Warta Ekspor: Fesyen Muslim Indonesia (Export News: Indonesia Muslim Fashion). (n.d.). Retrieved from http://djpen.kemendag.go.id/app_frontend/admin/docs/publication/9871447132408.pdf 


\section{$2^{\text {nd }}$ International Conference on Advanced Research in Social Sciences \& Humanities}

Directorate General of Small Business Industry. (2015). Mimpi Indonesia Kiblat Fashion Muslim Dunia (Indonesia's Dream as The Centre of The World's Muslim Fashion). (n.d.). Retrieved from http://www.kemenperin.go.id/artikel/4051/MimpiIndonesia:Kiblat-Fashion-Muslim-Dunia

Geurin-Eagleman, A. N., \& Burch, L. M. (2016). Communicating via photographs: A gendered analysis of Olympic athletes' visual self-presentation on Instagram. Sport Management Review, 19(2), 133-145. https://doi.org/10.1016/j.smr.2015.03.002

Goffman, E. (1959). The presentation of self in everyday life. Great Britain: Pelican Books.

Hidayat, M. W. (2016). 3 Media Sosial Favorit Pengguna Internet Indonesia (3 Social Media Favourites According to Indonesian Internet Users). Retrieved from http://tekno.liputan6.com/read/2634027/3-media-sosial-favorit-pengguna-

Hogan, B. (2010). The Presentation of Self in the Age of Social Media: Distinguishing Performances and Exhibitions Online. Bulletin of Science, Technology \& Society, 30(6), 377-386. https://doi.org/10.1177/0270467610385893

Lewis, R. (2007). Veils and sales: Muslims and the spaces of postcolonial fashion retail. Fashion Theory - Journal of Dress Body and Culture, 11(4), 423-442. https://doi.org/10.2752/175174107X250235

Marwick, A., \& Boyd, D. (2011). To See and Be Seen: Celebrity Practice on Twitter. Convergence: The International Journal of Research into New Media Technologies, 17(2), 139-158. https://doi.org/10.1177/1354856510394539

Nisa, E. F. (2018). Creative and Lucrative Da'wa: The Visual Culture of Instagram amongst Female Muslim Youth in Indonesia. Asiascape: Digital Asia, 5, 68-99.

https://doi.org/10.1163/22142312-12340085 Papacharissi, Z. (2012). Without You, I'm Nothing: Performances of the Self on Twitter. International Journal of Communication, 6 , 1989-2006. https://doi.org/1932-8036/20120005

Patton, M. Q. (1990). Qualitative evaluation and research methods (2nd ed.). Sage Publications.

Peterson, K. M. (2016a). Beyond Fashion Tips and Hijab Tutorials : The Aesthetic Style of Islamic Lifestyle Videos Lifestyle Videos on YouTube and Islamic Fashion Anxiety over Muslim Women's Appearances. Film Criticism, 1-20.

Peterson, K. M. (2016b). Islamic Fashion Images On Instagram and the Visuality of Muslim Women. In R. A. Lind (Ed.) (pp. 247-263). Routledge.

Piela, A. (2013). Claiming religious authority: Muslim women and new media. In M.

Lövheim (Ed.), Media, Religion and Gender Key Issues and New Challenges. Routledge.

Pink, S., Horst, H., Postill, J., Hjorth, L., Lewis, T., \& Tacchi, J. (2016). Digital Ethnography: Principles and Practice. SAGE Publications Ltd.

Postill, J., \& Pink, S. (2012). Social media ethnography: The digital researcher in a messy web. Media International Australia, (145), 123-134.

https://doi.org/10.1177/1329878X1214500114 
Sas, C., Dix, A., Hart, J., \& Ronghui, S. (2009). Dramaturgical capitalization of positive emotions: The answer for Facebook success? Proceedings of the 23rd British HCI Group Annual Conference on People and Computers: Celebrating People and Technology, 120-129. Retrieved from http://eprints.lancs.ac.uk/42424/

Schmidt, J. H. (2013). Practices of Networked Identity. In J. Hartley, J. Burgess, \& A. Bruns (Eds.), A Companion to New Media Dynamics (pp. 365-374). Blackwell Publishing Ltd. https://doi.org/10.1002/9781118321607.ch24

Smith, L. R., \& Sanderson, J. (2015). I'm Going to Instagram It! An Analysis of Athlete SelfPresentation on Instagram. Journal of Broadcasting \& Electronic Media, 59(2), 342358. https://doi.org/10.1080/08838151.2015.1029125

State of the Global Islamic Economy Report. (2015). Dubai the capital of islamic economy. https://doi.org/10.1017/CBO9781107415324.004

Sundén, J. (2003). Material Virtualities. New York: Peter Lang Publishing.

Thumim, N. (2012). Self-representation and digital culture. Self-Representation and Digital Culture. https://doi.org/10.1057/9781137265135

Waninger, K. (2015). The Veiled Identity : Hijabistas, Instagram and Branding In The Online Islamic Fashion Industry. Georgia State University. Retrieved from http://scholarworks.gsu.edu/wsi_theses/48 